\title{
PHYSICAL CONDITIONS AND MICROCLIMATE OF TWO Cynopterus SPECIES ROOSTS IN AN ABANDONED VILLAGE IN LAMBOR, PERAK
}

\author{
MOHD RANI ISMAIL HASNIM ${ }^{1}$, HAO-CHIH KUO ${ }^{2}$, SHAHRUL MOHD SAH ${ }^{3}$ AND LEE-SIM \\ $\mathrm{LIM}^{* 1}$
}

${ }^{1}$ School of Distance Education, ${ }^{3}$ School of Biological Sciences, Universiti Sains Malaysia, Minden, 11800 Pulau Pinang, ${ }^{2}$ Biodiversity Research Center, Academia Sinica, Taipei, 11529, Taiwan

*Corresponding author: leesim.lim@gmail.com

Submitted final draft: 21 January 2020 Accepted: 29 February 2020

http://doi.org/10.46754/jssm.2020.07.007

\begin{abstract}
This study aimed to investigate the microclimate and physical conditions of the detected Cynopterus fruit bats' roosts in an abandoned village, west coast of Peninsular Malaysia. Two abandoned wooden houses as permanent bat roosts were selected: one at an exposed spot with higher damaged condition; another one was less damaged and covered with wild vegetation. Bats were trapped in their roost, identified as Cynopterus horsfieldii and Cynopterus brachyotis. Microclimate conditions of both bat roosts were recorded twice at 08:00 and 12:00 each day for seven weeks. Microclimate analyses show the more covered roost had significant lower mean for roost temperature, light intensity, and wind speed than the more exposed roost, but no significant difference between the humidity of both roosts. Daily roost counts at noon reveals more Cynopterus bat individuals roosting at the less exposed and isolated roost consistently during the study, indicates this genus still prefer a more sheltered roost without human activities despite having adapted well to urbanisation. Our findings from this study and site observations on the returning wildlife suggested this abandoned anthropocene with vegetation regrowth has potential to be a refuge to forest bats and wildlife that are suffering from habitat loss yet cannot fully adapt to anthropogenic habitat..
\end{abstract}

Keywords: Roosting ecology, old world tropics, Peninsular Malaysia.

\section{Introduction}

Malaysia hosts at least 110 species of bats, which is about $9 \%$ of the total 1,240 bat species in the world (Simmon, 2005; Tamblyn et al., 2006; Lim et al., 2017). Of more than 110 species, 13 of them are endemic to Malaysia (Simmons, 2005; Francis et al., 2007). In terms of Pteropodid bats, both Bornean and Peninsular Malaysia host a total of 18 species from 11 genera place under subfamily Pteropodinae and Macroglossinae (Rovie-Ryan et al., 2008).

Cynopterus genus, especially C. brachyotis, is the most common and widespread fruit eating bat genus in Peninsular Malaysia (Hall et al., 2004; Mohd-Azlan et al., 2005; Khan et al., 2007; Francis, 2008; Tingga et al., 2012; Jayaraj et al., 2013; Azuan et al., 2016; Zahidin et al., 2016; Jayaraj et al., 2016; Pounsin et al., 2018; Muhamad Aidil et al., 2018; Fakhrul-Hatta et al., 2018; Mohd-Ridwan et al. 2018; Kahn et al., 2019). To date, three species of Cynopterus bat genus were recorded in Peninsular Malaysia i.e. Cynopterus brachyotis (Lesser Short-nosed Fruit Bat), Cynopterus horsfieldii (Horsfield's Fruit Bat), and Cynopterus sphinx (Greater Short-nosed Fruit Bat). These species can be morphologically distinguished based on the molar teeth's structure, muzzle's shape, forearm size range and body mass range when captured alive in the field (Kingston et al., 2006; Francis, 2008). Of these three most widespread Cynopterus species, maternal phylogeography shows Cynopterus brachyotis is a complex of six distinct lineages that even haplogroups of $C$. sphinx and C. horsefieldii were nested within this complex (Campbell et al., 2004). This complex has eight subspecies within IndoMalayan region and $C$. b. brachyotis is the subspecies found in the lowland of Peninsular Malaysia (Simmon, 2005). C. b. brachyotis was later examined and found to consist at least two sympatric, ecological-distinct lineages, namely the Sunda lineage and the Forest lineage 
from morphological and molecular approaches (Campbell et al., 2004; Abdullah \& Jayaraj, 2006; Kingston et al., 2006; Francis, 2008; Jayaraj et al., 2012a; 2013). Still, identification of Sunda and Forest lineages of C. b. brachyotis can be challenging, particularly identifying the bats alive in the field. Thus, Jayaraj et al. (2012a) developed a morphometrics-base multivariate analysis model to aid the process, to compliment traditional morphological and conservation genetics approaches (Abdullah, 2003; Campbell et al., 2004; 2006a).

Cynopterus spp. is indeed an important seed disperser in Old World tropics: C. brachyotis feed on fruits from 54 plant species such as Terminalia catappa (ketapang), Musa spp. (banana), and Psidium guajava (guava) (Tan et al., 1998). The main diet of C. sphinx consists of fruits (e.g. Manilkara zapota (ciku), Psidium guavaja (guava), Mangifera indica (mango), Musa spp. (banana)) and nectar (e.g. from flowers of Ceiba pentandra (kapok tree) and Parkia speciosa (petai)) (Advani, 1982). C. horsefieldii consume "big bang" fruits and flowers from lowland rain forest during the season (Hodgkison et al., 2004) but depend on the plant-base food resources from the secondary and urban habitats in the nearby forest the whole year (Hodgkison, 2001). The role of Cynopterus genus as seed dispersal for Old World tropical rainforest plant species may still be under estimated, as later study still reported fruit remnants from additional eight plant species in the diet of $C$. brachyotis and $C$. horsefieldii that had never been reported before year 2010 (Fletcher et al., 2012).

Current knowledge on bat evolution in terms of morphology, physiology and behaviour for roosting inform us roost choice of bats plays a very important role in their ecology and evolutionary process (Kunz, 1982; Kunz \& Lumsden, 2003), determining their survival and fitness to shelter from the weather, protection from predators, places of mate and rear young (Vonhof \& Barclay, 1996; Kunz et al., 2003; Carmi et al., 2013). Therefore, each bat species has its own roost preferences to uniquely suit to their physical and physiological needs. This phenomenon can be easily observed on a bat community roosting within the same cave, that certain bat species were found only roost within specific microhabitat inside the cave than other neighbouring bat species in the same cave (Wijayanti, 2011; Shazali et al., 2017; Morni et al. 2018). Due to these special needs of roosts, many bats face problems associated with the physical structure and the microclimate conditions of roosts during the selection of roosting site (Craig \& Brigham, 2005).

In terms of roost choice, Cynopterus brachyotis found either roosting as a small harem in the caves, buildings, broad and large leafed plants, or foliage-modified tents (Wijayanti, 2011; Hodgkison, 2001). Cynopterus horsefieldii was also observed to roost in small groups, under or in large leafed trees such as banana plants (Musa spp.), and foliage-modified tents. While roosting in the caves, $C$. horsefieldii prefer limestone solution cavities and close to the cave openings. Unlike $C$. brachyotis, $C$. horsefieldii are also reported to roost under the bird nest's ferns (Asplenium nidas) and tree cavity high up at canopy level (Funakoshi \& Zubaid, 1997; Hodgkison, 2001; Campbell et al., 2006b). In fact, Cynopterus sphinx, Cynopterus brachyotis and Cynopterus horsefieldii have all been found to have tent-building behaviour occasionally when they roost in plants (Bhat \& Kunz, 1995; Tan et al., 1997; Campbell, 2016b).

Cynopterus spp. can be found co-existing in one area such as in Perlis State Park and Taiping, Perak (Campbell et al., 2006a; 2006b) and in Gunung Stong State Park (Jayaraj et al., 2012b). Interspecies niche overlap on roost sites happens in these three Cynopterus species in Peninsular Malaysia but at low chance (Campbell et al., 2016b). Campbell et al., (2006a) noted the height of roosts which is used by Cynopterus horsfieldii was observably lower than any of roosts that are occupied by both $C$. sphinx and C. brachyotis. In the vegetation type of roost, $C$. sphinx usually built their shelter about $2.4-6.0$ meter above the ground for no more than a few days before they move out (Storz \& Kunz, 1999). Although the knowledge on the microclimate of Cynopterus spp. preferable roost sites are still lacking, bats in general tend to select roost site 
which can maintain an optimum microclimate for the bats (Betts, 1998; Sedgeley, 2001) and provide better insulation (Nicolai, 1986).

Kampung Lambor Kiri was founded roughly in 1890. It was abandoned for more than two decades and currently only three houses are still being occupied by the local farmers, with most of other houses and farms have been replaced by bushes and secondary forest. Some of the wildlife species such as Cynopterus spp., otters, squirrels, wild boars, fireflies, snakes, and hornbills were observed visiting the village (Raja Amir Bin Raja Harun, personal communication). Therefore, we presume the biodiversity here is increasing over the last twenty over years, which makes this village more interesting for biological studies. Thus, this study aims to describe the types of the detected Cynopterus bat's permanent roost from this abandoned anthropocene with vegetation regrowth habitat and investigate the microclimate of these roosts.

\section{Materials and Methods}

\section{Field Site}

Kampung Lambor Kiri is a small village located in Lambor Kiri, Perak Tengah district (4'16'24.9' $\left.\mathrm{N}, 100^{\circ} 53^{\prime} 43.8^{\prime \prime} \mathrm{E}\right)$, nine meter above sea level and $40 \mathrm{~km}$ from Ipoh city. The study area was focused on the area by the riverside, where abandoned houses can be found along Perak River bank (Figure 1). Kampung Lambor Kiri is believed to be established before World War II thus some of the houses were over 100 years of age (Late Mr. Megat Arifin Bin Megat Ahmad, personal communication, 1993). The size of Kampung Lambor Kiri population was estimated at about 300 peoples based on the last national census (Department of Statistics Malaysia, 2014). However, there were only three houses which are still permanently occupied during the time this study was conducted. Nearest primitive forest, Hutan Rizab Pulau Tiga, is about 4 - 5.5 $\mathrm{km}$ to the west $\left(4^{\circ} 15^{\prime} 01.0^{\prime \prime} \mathrm{N}, 100^{\circ} 56^{\prime} 18.1^{\prime \prime} \mathrm{E}\right)$. Primitive vegetation in Kampung Lambor Kiri consist of many small herb species and woody plant species which grow from land to riverside including kapok tree (Ceiba pentandra) and asam gelugur (Garcinia atroviridis). The crops that are planted systematically and in larger scale are oil palm, banana, paddy and durian. Fruit trees like guava, rambutan (Nephelium lappaceum), pulasan (Nephelium mutabile), kuini (Mangifera odorata), and papaya are mostly grown wild after significant human population decreased in the area near to three decades ago.

\section{Bat Captures and Handling}

In the first night of this study (25 October 2014), all anthropogenic buildings in Kampung Lambor Kiri were surveyed for the occurrence of bats. For this, individual bats were captured inside buildings using either a hand net or mist nets. Mist nets were set up surrounding the building before $7.30 \mathrm{pm}$, and afterward were checked with a time interval of 15 minutes for each. From each captured bat, several measurements were taken including those for the external body parts and body mass. Based on these measurements plus a few qualitative characters, captured bats were identified to species using keys provided by Kingston et al. (2006) and Francis (2008). Captured bats were released immediately after the process.

\section{Bat Occurrence, Physical Conditions and Microclimates of the Roosts}

During the bat survey described above, two abandoned houses were confirmed to be utilised by bats as roosts (hereafter referred to as 'bat roosts'). For these bat roosts, we recorded their geographic coordinates, major building materials and opening directions. In addition, a measuring tape was used to measure their dimensions including lengths, widths, heights of the floors above the ground and heights from the floors to the ceilings.

Visits were made to the two bat roosts from 1 November 2014 to 21 December 2014, during which daily records were made of the number of roosting bats at noon $(12.00 \mathrm{pm})$ without conducting bat captures. During this study period, a Lutron multifunction meter 


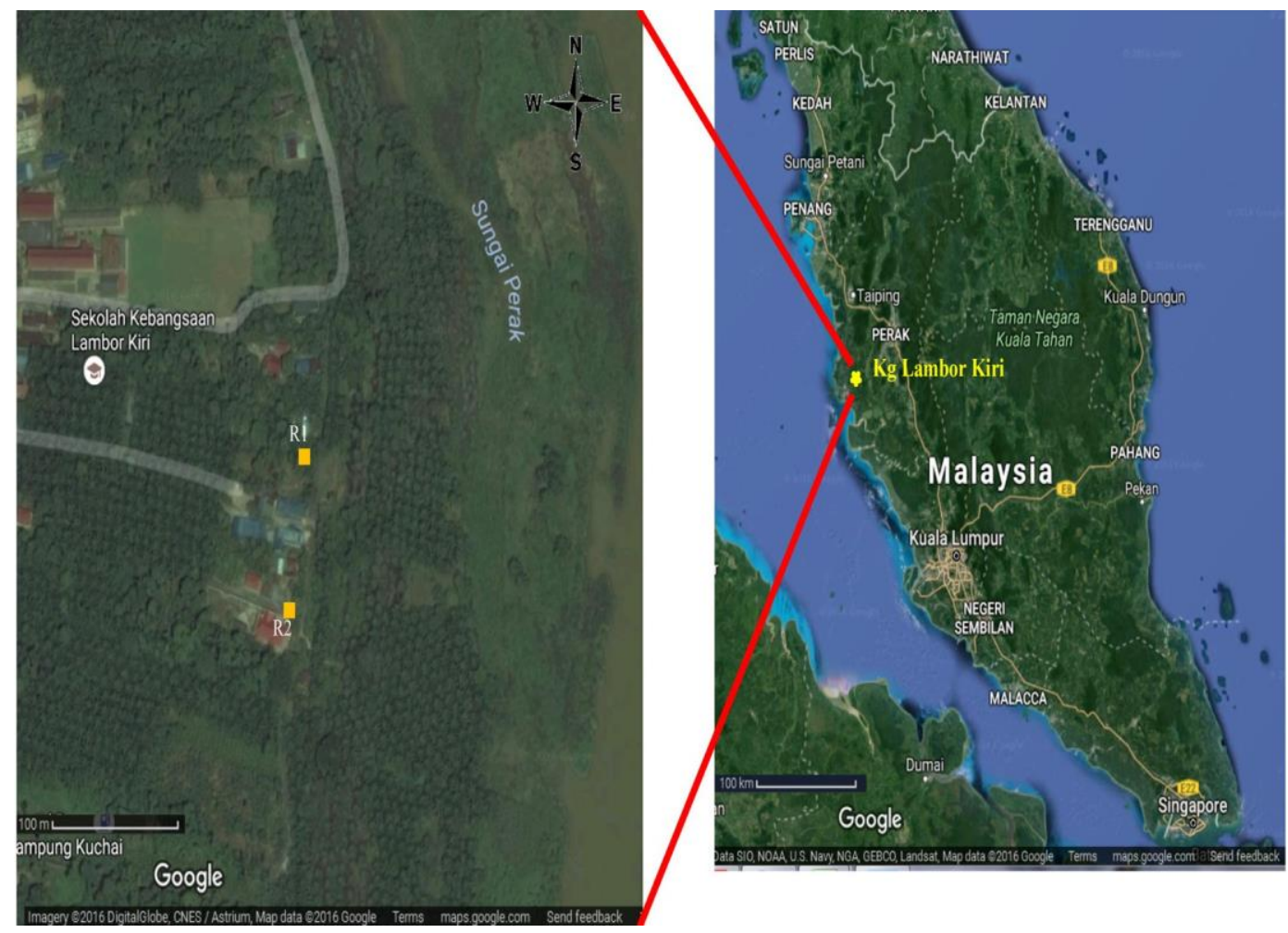

Figure 1: Satellite image of Kampung Lambor Kiri and the locations of the two identified roots in the village (left), as well as the location of the village in Peninsular Malaysia (right).

(Google Maps, 2016)

model EM-9300SD was used to measure the microclimate parameters inside the roosts including temperature $\left({ }^{\circ} \mathrm{C}\right)$, humidity $(\%)$, light intensity (Lux) and wind speed (m/s). Values of these parameters were automatically recorded by the Lutron meter daily at 8:00 h (e.g. a time during the day when most bats had just returned from forages, and thus microclimates then could be most relevant to bats' active choices of the roosts) and 12:00 h (e.g. during the midday which roost exterior received maximum sunshine and indoor temperature is expected to be the highest, with all the bats fully settling down and at rest.).

All four collected microclimate parameters were analysed to obtain their daily average and its standard deviation for morning readings, noon readings and overall daily (total of morning and noon) readings respectively. The median, minimum and maximum of each parameter for the morning period were also determined for both respective roosts. The differences between the two bat roosts in terms of the four selected microclimate parameters were evaluated using Wilcoxon signed-ranked (WSR) tests. All calculations were performed in the coin package (Hothorn et al., 2006; Hothorn et al., 2008) of R (R Core Team, 2016).

\section{Results and Discussion}

Among buildings in Kampung Lambor Kiri, including occupied and abandoned houses, small storerooms and shelters, two abandoned houses (Figure 2) were found to accommodate bats. The first one (R1) locates at coordinate $4^{\circ} 16^{\prime} 35^{\prime}$ 'N $100^{\circ} 53^{\prime} 40^{\prime \prime} \mathrm{E}$. The second one (R2), which is 248 meters away from R1, locates at coordinate $4^{\circ} 16^{\prime} 31^{\prime \prime} \mathrm{N}, 100^{\circ} 53^{\prime} 47^{\prime \prime} \mathrm{E}$. 


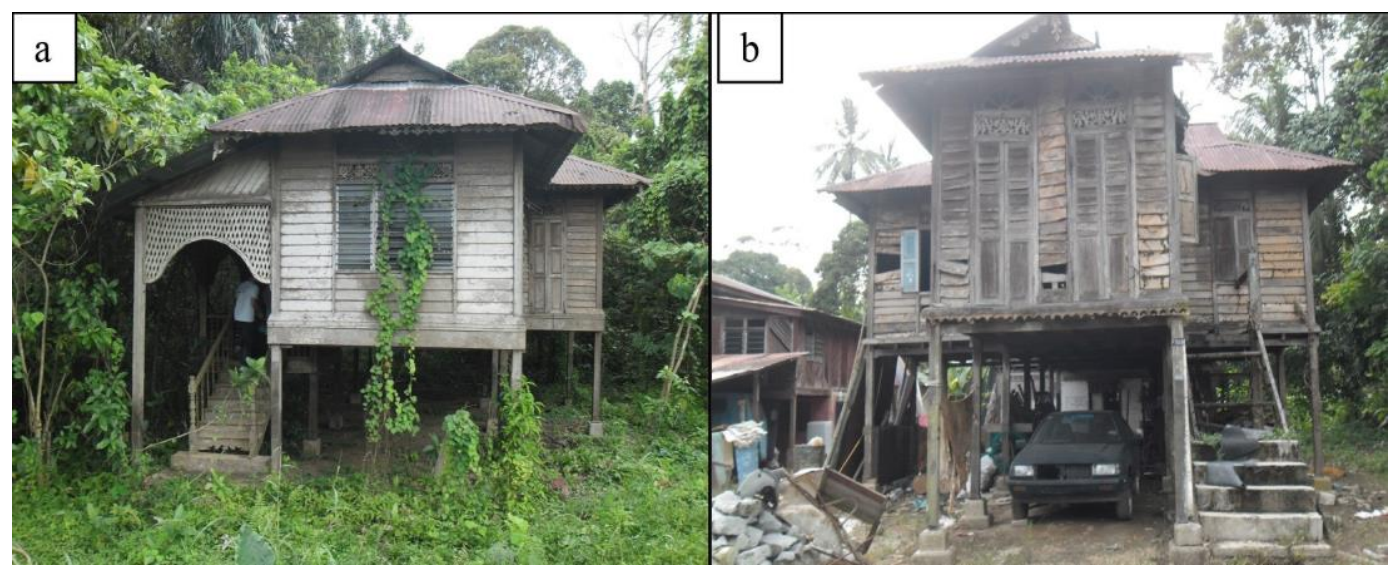

Figure 2: Two abandoned houses detected with bats. a) The front view of R1, hidden behind bushes and shrubs;

b) R2 adjacent to a house (left) which is still occupied, with clear front yard and damaged roof and wall

R1 is a Malay traditional house which was abandoned since early 1970s (Haji Azmi Bin Kulop Ismail, personal communication, 28 October 2014). It faces northeast and thus sunrise radiated its front right side. The main building material of R1 was wood while the roof was covered by corrugated iron materials. Concrete elements were present on the house poles. The length and the width of the house were $6 \mathrm{~m}$ and 5 $\mathrm{m}$, respectively. The ceiling was $2.4 \mathrm{~m}$ above the floor level, $1.5 \mathrm{~m}$ above the ground. The front yard and the back yard were filled with shrubs and wild growing trees, respectively, and the front window was partially covered by creeper plants. During the first visit to R1, a few bats were discovered hanging solitary or in pairs in the living room as well as in the centre of the house which was a corridor leading to the bedroom and the kitchen. One bat was caught with the use of a hand net, which was identified as Cynopterus horsfieldii (Table 1).

$\mathrm{R} 2$ is also a Malay traditional house which was abandoned since early 2000s (Puteri Norlila
Binti Megat Arifin, personal communication, 14 January 2015). This house faced northeast and the sunrise radiated its front right side. Like R1, R2 was mainly made of wood and its roof was also covered by the corrugated iron materials. However, R2 has additional building made of bricks and cement on the ground floor which was used as a kitchen. The length, the width, the height between the ceiling and the floor were $10 \mathrm{~m}, 5 \mathrm{~m}$ and $3 \mathrm{~m}$ respectively. The height of the floor level from the ground was $2 \mathrm{~m}$. R2 was barely hidden by vegetation, endowing a relatively bright environment inside the house. Some windows were damaged and widely open, allowing wind to enter the room, promoting better air circulation. R2 is also build adjacent to another house which is still occupied by a family, and thus there are human activities at ground level of R2. In our first visit to R2, we found bats hanging solitary in the centre of the house, kitchen and bedroom. One bat was captured using mist net, which was identified as Cynopterus brachyotis 'Forest' lineage (Table $1)$. 
Table 1: Bat individuals captured at the roost sites on 25 October 2014.

\begin{tabular}{lll}
\hline Roost & R1 & R2 \\
Species & Cynopterus horsfieldii & Cynopterus brachyotis \\
Body mass & 69 gram & 36 gram \\
Forearm length & $75 \mathrm{~mm}$ & $61 \mathrm{~mm}$ \\
Tibia length & $27 \mathrm{~mm}$ & $23 \mathrm{~mm}$ \\
Ear height & $18 \mathrm{~mm}$ & $16 \mathrm{~mm}$ \\
Tail length & $15 \mathrm{~mm}$ & $14 \mathrm{~mm}$ \\
Tail character & Distinct from membrane & Distinct from membrane \\
Lower incisors & 2 pairs & 2 pairs \\
Sex & Female & Male \\
Other characters & slenderer skull \& elongated muzzle & short stout muzzle \\
& & bright orange colours around shoulder \\
\hline
\end{tabular}

The microclimate parameters within the roosts were then investigated at $0800 \mathrm{am}$ (e.g. during the time when the bats are actively choosing an ideal roost for resting) and at $1200 \mathrm{pm}$ (e.g. during the mid-day when most of the bats are at rest and the roost temperature may be the highest due to maximum and direct sunshine on the roost) for a continuous 51-day period within the subsequent two months after the first field trip. The trend for each microclimate parameter measured for both roosts were shown in Figure 3 and Table 2. Although both R1 and R2 were facing the same direction and located along the same road in the village but show differentlevel of enclosure and thus provide slightly different microclimate conditions to accommodate the bats. Based on 51 days of record, R1 had the minimum temperature of $27^{\circ} \mathrm{C}$ and maximum temperature of $33^{\circ} \mathrm{C}$, with $50 \%$ of the time fluctuating between $28^{\circ} \mathrm{C}$ and $30^{\circ} \mathrm{C}$. Average temperature of the $\mathrm{R} 1$ was $29^{\circ} \mathrm{C} \pm 1^{\circ} \mathrm{C}$. R2 had the minimum temperature at $27^{\circ} \mathrm{C}$ as well but its maximum temperature was $1^{\circ} \mathrm{C}$ higher than $\mathrm{R} 1$. R2's temperature for morning and noon was on average at $30^{\circ} \mathrm{C} \pm 1.04^{\circ} \mathrm{C}$, which half of the data shown fluctuating between $29^{\circ} \mathrm{C}$ and $31^{\circ} \mathrm{C}$ (Figure 3a, Table 2). Humidity wise, $\mathrm{R} 1$ and R2 had the minimum humidity at 53\% relative humidity $(\mathrm{RH})$ and maximum humidity of $73 \%$ RH but R2 has an outlier reading at $52 \%$ RH. However, the higher enclosure level of $\mathrm{R} 1$ reduced the speed of indoor air ventilation, causing the humidity data of R1 to have a bigger range for the third and the first quartiles than

Table 2: Averaged temperature, humidity, light intensity, wind speed and occurrence of human activities of R1 and R2 for morning, noon and overall (morning and noon) sessions

\begin{tabular}{llll}
\hline & & \multicolumn{1}{c}{$\mathrm{R} 1$} & $\mathrm{R} 2$ \\
\hline Average Temperature & morning & $28 \pm 0.84$ & $29 \pm 0.9$ \\
$\left({ }^{\circ} \mathrm{C}\right)$ & noon & $31 \pm 1.40$ & $31 \pm 1.42$ \\
& overall & $29 \pm 1.00$ & $30 \pm 1.04$ \\
\hline Average Humidity & morning & $66 \pm 4.69$ & $65 \pm 4.48$ \\
$(\% \mathrm{RH})$ & noon & $59 \pm 5.80$ & $63 \pm 5.42$ \\
& overall & $62 \pm 3.67$ & $64 \pm 3.61$ \\
\hline Average light intensity & morning & $0.41 \pm 0.57$ & $1.37 \pm 0.66$ \\
$($ Lux $)$ & noon & $1.14 \pm 0.69$ & $3.39 \pm 2.17$ \\
& overall & $1 \pm 0.48$ & $2 \pm 1.25$ \\
\hline Average wind speed & morning & $0.02 \pm 0.04$ & $0.07 \pm 0.08$ \\
$(\mathrm{~m} / \mathrm{s})$ & noon & $0.02 \pm 0.05$ & $0.09 \pm 0.10$ \\
& overall & $0.0 \pm 0.04$ & $0.1 \pm 0.07$ \\
\hline Human activities & & No & Yes \\
\hline
\end{tabular}



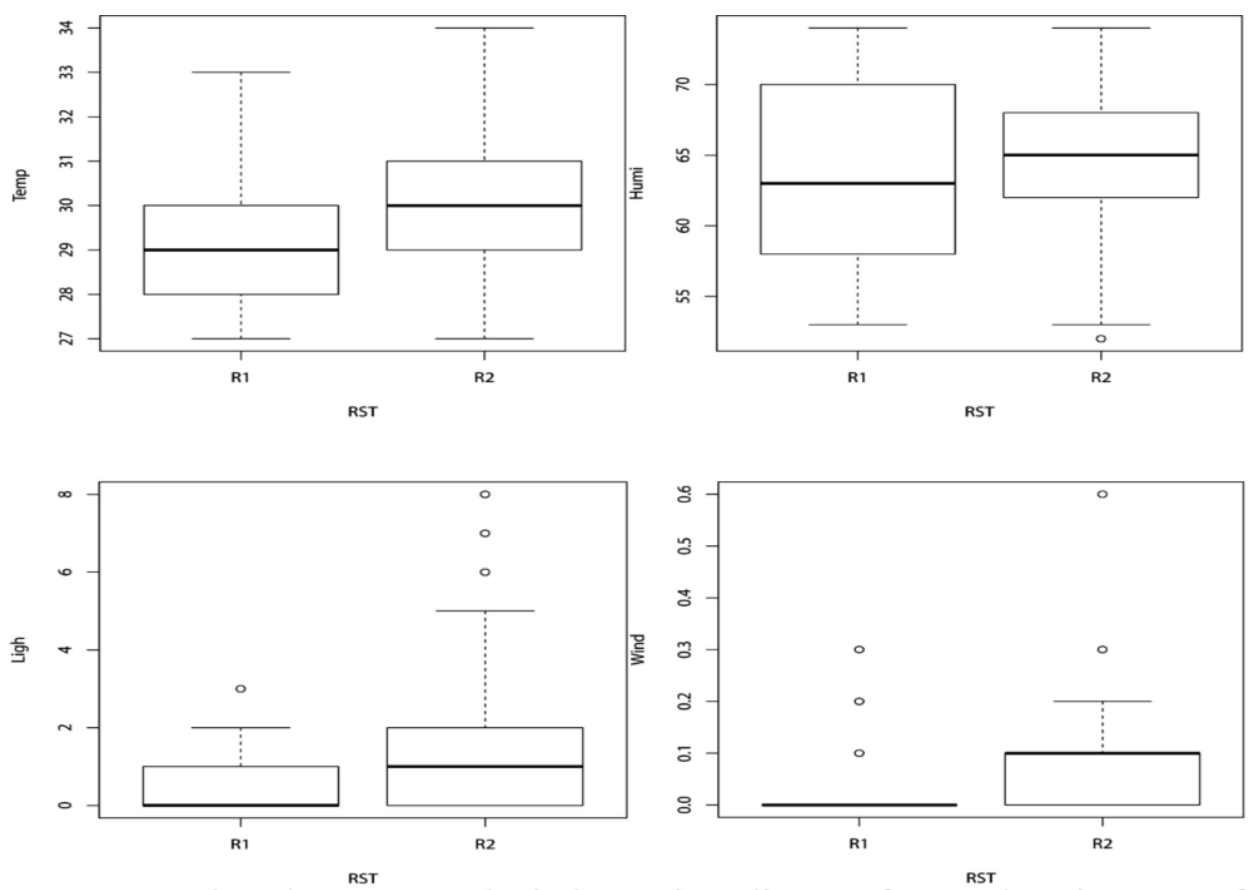

Figure 3: Box plots demonstrate the indoor microclimate of R1 and R2 in terms of a) temperature $\left({ }^{\circ} \mathrm{C}\right)$, b) humidity (\% Relative Humidity), c) light intensity (lux) and d) wind speed (meter/second). Bold lines within the plot indicate the median, upper and lower lines of the box indicate the third and the first quartiles respectively, lines not bold at extreme above or below the box are the highest or the lowest point whereas small circles are outliers

R2 (Figure 3b). The better enclosed conditions of $\mathrm{R} 1$ also remained at total darkness till 2 Lux and stagnant air most of the time, whereas maximum light intensity of R2 reached 5 Lux with maximum indoor wind speed that reached $0.2 \mathrm{~m} / \mathrm{s}$ (Figure $3 \mathrm{c}$ and $3 \mathrm{~d}$ ).

During the morning and noon within the study period, the average of indoor temperature, light intensity and wind speed were lower in R1 than in R2, while the humidity was about the same in these two bat roosts (Figure 4). Indeed, the differences in the former three parameters were statistically supported by WSR tests ( $\mathrm{Z}$
$=-5.768,-6.097$ and -3.753 for tests based on the temperature, the light intensity and the wind speed, respectively, and $\mathrm{P}<0.001$ in all cases); in contrast, the WSR test detected insignificant difference between R1 and R2 in terms of humidity $(\mathrm{Z}=0.568, \mathrm{P}>0.05)$. The microclimate conditions between the two roosts were actually affected by the level of exposure of the roost, as R1 which was in better physical conditions and covered by vegetation regrowth had lower temperature, light intensity and wind speed, in comparison to R2 which had wall and windows of the building torn and broken, with no vegetation regrowth surrounding it. 


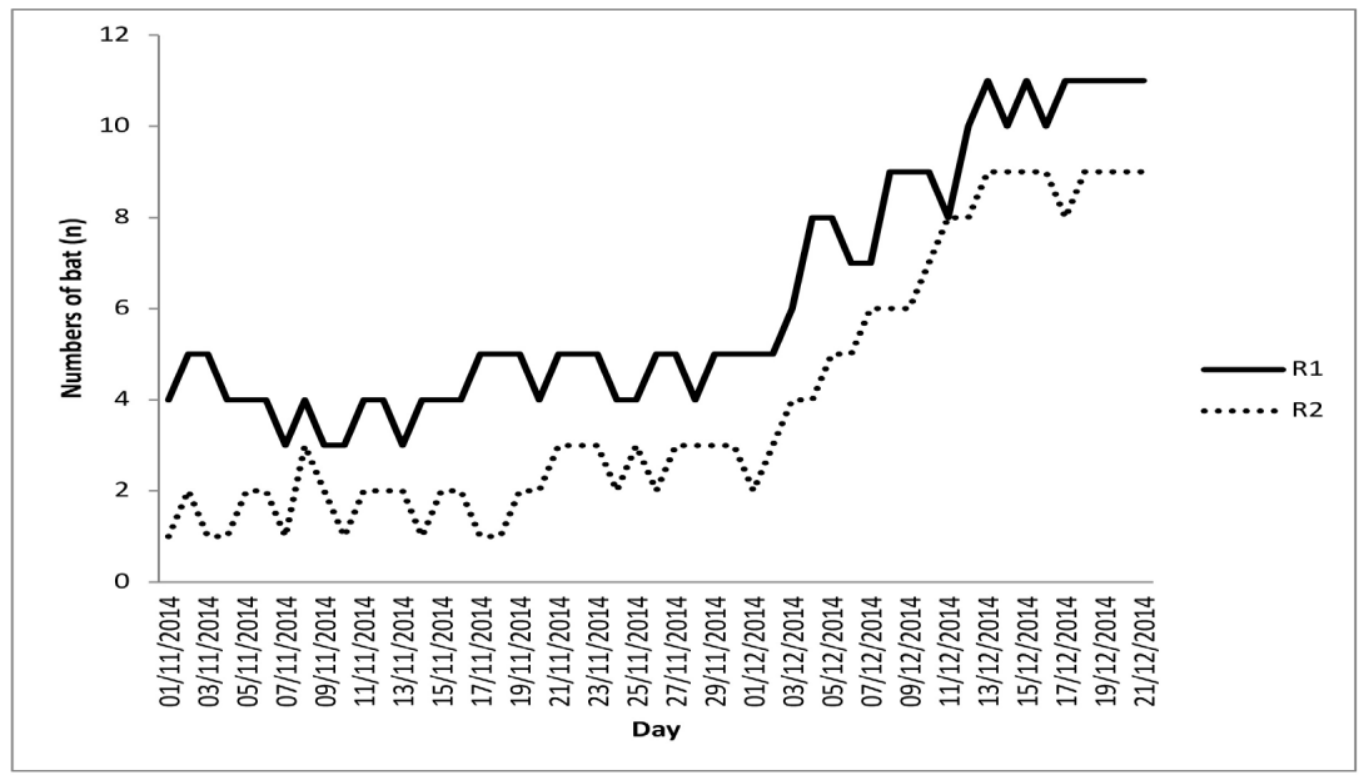

Figure 4: Roost counts on the total Cynopterus bats in R1 (bold solid line) and R2 (dotted line) at 12:00pm

Although C. Horsefieldii from R1 and $C$. Brachyotis were captured from R2, it did not mean that both houses were only roosted by the only identified species respectively. However, all bat individuals occupying $\mathrm{R} 1$ and $\mathrm{R} 2$ were observed to have characters including a white margin along the pinna and white finger bones, which are unique to Cynopterus genus, as described in Kingston et al., (2006) and Francis (2008). Bats from the genus Cynopterus can coexist in the same area and sharing the same roost, as reported by Jayaraj et al., (2012b) based on their findings from Gunung Stong State Park, Kelantan, Malaysia. Cynopterus brachyotis was also found roosting under the trees as well as open areas of caves with brighter conditions (Khan et al., 2007).

During the period of our survey, a number of bats in both roosts were changing each day but slightly increased in December (Figure 4). Figure 4 also shows R1 consistently accommodate more bat individuals than $\mathrm{R} 2$ throughout the period of the study. This may be due to the lower exposure within R1 than R2, making $\mathrm{R} 1$ a preferable roosting choice for the bats in terms of the darker, more stable microclimatic conditions and no human disturbance (Figure
3, Table 2). Some volant animals such as birds were found to prefer sheltered roost sites in terms of wind velocity and cold air for the benefit of their energy saving (Walsberg, 1985; Jenni, 1991). C. brachyotis and C. horsefieldii from 12 Javan caves chose to roost in hot and dry conditions of above $28.5^{\circ} \mathrm{C}$ and less than $65 \%$ of humidity (Wijayanti, 2011). Both Cynopterus roosts in our study also have roost temperature at least $28^{\circ} \mathrm{C}(\mathrm{R} 1)$ and the humidity level at noon for both roosts also around 59\% (R1) and 63\% (R2). However, the Cynopterus bats in Wijayanti's (2011) study were roosting in far brighter conditions of at least $55 \mathrm{Lux}$, and more windy conditions (between 14.2-23.4 m/s) in the four out of five detected roosts. The fifth Cynopterus roost had $0 \mathrm{~m} / \mathrm{s}$, which is similar to the roosts in our study, R1 and R2. Comparison between our study and Wijayanti's (2011) study indicate Cynopterus brachyotis and Cynopterus horsefieldii have high tolerance on light intensity and air ventilation of their roost. Bat species may show diverse preferences in roost selection and microclimate of the roost may not be the main factor to consider all the time. For example, Panthetor lucasi was observed to prefer a bright zone, E. monticola was occupying the 
twilight and hottest zone, whereas Hipposiderid bats chose to roost in total-darkness and the coolest portion of Fairy Cave in Sarawak. (Rajasegaran et al., 2018). However, another study on the Wind Cave's bat community with ten residential bat species also showed various roosting preferences and revealed the bats from Wind Cave selected their ideal roost based on their body size and echolocation ability. Hence, closely related bat species at family level may share common features in terms of preferred roost choice (Morni et al. 2018).

Apart from the microclimate, cave structure and other physical parameters of the roost also important in bat's roost selection (Reid et al., 2011). The sound intensity within or surrounding the roosts, distance from cave entrance, cave passage dimension, light intensity, roost site structure, vegetation structure, distance from the roost to appropriate drinking and foraging areas are among the physical parameters that have been studied (e.g. Speakman et al., 1991; Entwistle et al., 1997; Jenkins, 1998; Reid et al., 2011; Wijayanti, 2011; Rajasegaran et al., 2018). In our case, since both roosts were built using similar materials and facing the same direction, the factors making $\mathrm{R} 1$ different from $\mathrm{R} 2$ would be the more sheltered conditions of $\mathrm{R} 1$ due to plant overgrowth as well as zero human visit or activities in R1. Given that the roost count of R1 was higher than the R2 all the time during our study period, indicates Cynopterus brachyotis and $C$. horsefieldii still prefer more sheltered roost with as low human occurrence as possible, if roost options are available (Figure 4). However, we are also not sure about their physiological change when roosting in more exposed roosts than the better sheltered roosts. This aspect is worth further study to understand the physiological fitness and life quality of fruit and nectar eating bats, which indirectly determine their survival in the short term and shape Cynopterus' evolution path in the long term. Nonetheless, the knowledge will also aid bat conservation programmes.

December 2014 (e.g. the second month of our study) onwards was the fruiting season in
Kampung Lambor Kiri. This season resulted in abundance of ripen fruits such as guava and rambutan from the abandoned fruit trees in the village as the fruits were not being harvested by human. Therefore, food source availability for frugivorous bats increased and the Cynopterus bat populations in the abandoned houses of the village also increased, as observed in R1 and R2 (Figure 4). In 1960s, C. brachyotis were observed to have two foraging seasons, which are the fruit foraging season and the floral parts foraging season (Lim, 1970). Marimuthu et al., (1998) reported harem males of Cynopterus sphinx foraged less than one kilometer from their day roost and tended to switch their foraging habitat during the dry season and when their favourite fruits were available (Bumrungsri et al., 2007). These foraging behaviours may cause Cynopterus bats switching their roost into Kampung Lambor Kiri during the fruiting season. Whether all species from Cynopterus genus share the same foraging behaviour or keep the same foraging behaviour over time regardless habitat change is another subject to be further examined.

Although Cynopterus bats, especially $C$. brachyotis are habitat generalists and adapted well in urban areas (Jayaraj et al. 2011), these bats are still exposed to threat of human-bat conflict (Fujita, 1988; Aziz et al., 2016; Anand \& Radhakrishna, 2017). Some residents allow bats to roost in their houses and accept the presence of bats within their areas. However, some other people, especially from the agricultural sector, consider bats as pests (Fujita, 1988; Agosta, 2002; Aziz et al., 2016) and ultimately trigger conflicts between human and bats. Meanwhile, the impacts of world climate change also affect the microclimate of their roosts (Welbergen et al., 2008) and may cause change in preferred roost choices for the bats. Therefore, studies on the roosting ecology of human-associated bat species in primitive and abandoned anthropogenic habitats should be encouraged to ensure the efficiency in human-associate bats' conservation programmes and facilitated in human-bat conflict solutions. 


\section{Conclusion}

This study reported the physical and microclimate conditions of two anthropogenic bat roosts accommodated bat species of genus Cynopterus in Kampung Lambor Kiri, an area which has been abandoned for nearly three decades with wild vegetation and food source regrowth. Conditions in roost R1 were more protected from light and wind, with lower temperature and no human activities. Meanwhile, R2 was more open to human presence and has more damaged windows and walls, causing the roost to be more exposed thus the high fluctuation in microclimatic parameters except humidity. Our two-month daily roost counts indicate R1 accommodated slightly more bat individuals than R2, even during the fruiting season when more Cynopterus bats shifted into the village, indicating the common Cynopterus bats which show successive adaptation to anthropocene still prefer sheltered roost sites isolated from humans.

\section{Acknowledgements}

This project was sponsored by a short-term grant scheme 304/PJJAUH/6313060 awarded to LeeSim Lim. We thank the remaining villagers from Kampung Lambor Kiri for their assistance and guidance during this study. We feel gratitude to get assistance from Nur Izzati Abdullah, Wong Cheng Min and Yan Qian Tan during our bat roost survey and bat species identification.

\section{References}

Anand, S. \& Radhakrishna, S. (2017). Investigating trends in human-wildlife conflict: is conflict escalation real or imagined? Journal of Asia-Pacific Biodiversity, 10(2), 154-161.

Aziz, S. A., Olival, K. J., Bumrungsri, S., Richards, G. C. \& Racey, P. A. (2016). The conflict between pteropodid bats and fruit growers: species, legislation and mitigation. Bats in the Anthropocene: Conservation of bats in a changing world. Cham: Springer, pp, 377-426.
Abdullah, M. T. \& Jayaraj, V. K. (2006). Preliminary investigation on the relationship of nominate $C$. brachyotis with the smallsized and large-sized $C$. brachyotis using clustering analysis. Sarawak Museum Journal, 62(83), 223.

Azuan, R., Gertrude, D., Nur Izzah Izzati, A., Noor Aisyah A. R., Pesiu, E., MuhamadAidil, Z., Fathini-Hakimi, R., Hasrulzaman, H., Mohamad-Abid, K., Nor Zalipah, M. \& Abdullah, T.M. (2016). Notes of bats in Pulau Bidong and Pulau Perhentian Besar, Terengganu, Malaysia. Journal of Sustainability Science and Management, (Special Issue) 1, 26-35.

Advani, R. (1982). Feeding, foraging and roosting behaviour of the fruit eating bats and damage to fruit crops in Rajasthan and Gujarat. Saeugeteirkundliche mitteilungen, 30(1), 46-48.

Agosta, S. J. (2002). Habitat use, diet and roost selection by the Big Brown Bat (Eptesicus fuscus) in North America: a case for conserving an abundant species. Mammal Review, 32, 179-198.

Bhat, H. R. \& Kunz, T. H. (1995). Altered fruit/flower clusters of the kitul palm used as roosts by the short-nosed fruit bat, Cynopterus sphinx (Chiroptera: Pteropodidae). Journal of Zoology, 235, 597-604.

Betts, B. J. (1998). Roosts used by maternity colonies of silver-haired bats in Northeastern Oregon. Journal of Mammalogy, 79(2), 643-650.

Bumrungsri, S., Leelapaibul, W. \& Racey, P. A. (2007). Resource Partitioning in Sympatric Cynopterus bats in Lowland Tropical Rain Forest, Thailand. Biotropica, 39, 241-248.

Campbell, P., Schneider, C. J., Adnan A. M., Zubaid, A. \& Kunz, T.H. (2004). Phylogeny and phylogeography of Old World fruitbats in the Cynopterus brachyotis complex. Molecular Phylogenetics and Evolution, 33, 764-781. 
Campbell, P., Schneider, C. J., Adnan, A.M., Zubaid, A. \& Kunz, T.H. (2006a). Comparative population structure of Cynopterus fruit bats in Peninsular Malaysia and southern Thailand. Molecular Ecology, 15, 29-47.

Campbell, P., Reid, N.M., Zubaid, A., Adnan, A. M. \& Kunz, T. H. (2006b). Comparative roosting ecology of Cynopterus (Chiroptera: Pteropodidae) fruit bats in Peninsular Malaysia. Biotropica, 38, 725-734. doi:10.1111/j.1744-7429.2006.00203.x

Carmi, K., Shai, D. \& Berry, P. (2013). Roost selection by female Hemprich's long-eared bats. Behavioural Processes, 100: 131-138.

Craig, K. R. W. \& Brigham, R. M. (2005). Physiological and ecological aspects of roost selection by reproductive female hoary bats (Lasiurus cinereus). Journal of Mammalogy, 86(1), 85-94.

Department of Statistics Malaysia. (2014). Population Distribution by Local Authority Areas and Mukims, http://www.statistics. gov.my/portal/download_Population/ files/ population/05Jadual_Mukim_negeri/ Mukim_Perak.pdf

Fujita, M. S. (1988). Flying foxes and economics. Bats, 6(1), 4-9.

Khan, F. A. A., Sazali, S. N., Jayaraj, V. K., Siali Aban, M., Zaini, K., Ketol, B., Ryan, J. R., Ahmad Mashur J., Hall, L. S. \& Abdullah, M. T. (2007). Survey of bats in the tropical lowland dipterocarp forest of Bako National Park, Sarawak, Malaysian Borneo. Sarawak Museum Journal, 63(84), 267.

Khan, F. A. A., Shazali, N., Latip, N. \& Azhar, I. (2019). Short communication into the Heart of Borneo: Mammals of Upper Baleh, Sarawak. Journal of Sustainability Science and Management, 14(2), 173-182.

Fakhrul-Hatta, S. N. N., Nelson, B. R., Shafie, N. J., Zahidin, M. A. \& Abdullah, M. T. (2018). Linkages between Chiropteran diversity and ecosystem services for sustainable fragmented forest conservation. Data in Brief, 21, 2089-2094.

Fletcher, C., Zubaid, A. \& Kunz, T.H. (2012). Fruit diet of frugivorous bats (Cynopterus brachyotis and Cynopterus horsfieldii) in tropical hill forests of Peninsular Malaysia. Mammalia, 76(4), 389-397.

Francis, C. M., Kingston, T. \& Zubaid, A. (2007). A new species of Kerivoula (Chiroptera: Vespertilionidae) from Peninsular Malaysia. Acta Chiropterologica, 9(1), 1-12.

Francis, C.M. (2008). A field Guide to the Mammals of South-East Asia. London: New Holland Publishers (UK) Ltd.

Funakoshi, K. \& Zubaid, A. (1997). Behavioural and reproductive ecology of the dog-faced fruit bats, Cynopterus brachyotis and C. horsfieldi, in a Malaysian rainforest. Mammal Study, 22, 95-108.

Google Maps. (2016). Map \& geographical information of Kampung Lambor Kiri, https://www.google.com.my/maps/place/ Kampung+Lambor+Kiri

Hall, L. S., Grigg, G. G. \& Moritz, C. (2004). Biogeography of fruit bats in Southeast Asia. Sarawak Museum Journal, 81, 191284.

Hodgkison, R. (2001). The Ecology of Fruit Bats (Chiroptera: Pteropodidae) in a Malaysian Lowland Dipteropcarp Forest, with Particular Reference to the Spottedwinged Fruit Bat (Balionycteris maculata, Thomas), Ph.D. dissertation, University of Aberdeen, Scotland, 189 pp.

Hodgkison, R., Balding, S.T., Zubaid, A. \& Kunz, T.H. (2004). Temporal variation in the relative abundance of fruit bats (Megachiroptera: Pteropodidae) in relation to the availability of food in a lowland Malaysian rain forest. Biotropica, 36, 522533.

Hothorn, T., Hornik, K., van de Wiel, M. A. \& Zeileis, A. (2006). A Lego System for Conditional Inference. The American Statistician, 60(3), 257-263. 
Hothorn, T., Hornik, K., van de Wiel, M. A. \& Zeileis, A. (2008). Implementing a Class of Permutation Tests: The coin Package. Journal of Statistical Software, 28(8), 1-23.

Jayaraj, V. K., Ketol, B., Marni, W., Sait, I., Mortada, M. J., Khan, F. A. A., Fong, P. H., Hall, L. S. \& Abdullah, M.T. (2011). Comparative distribution and diversity of bats from selected localities in Sarawak. Borneo Journal of Resource Science and Technology 1(1), 1-13.

Jayaraj, V. K., Laman, C. J. \& Abdullah, M. T. (2012a). A predictive Model to differentiate the fruit bats Cynopterus brachyotis and $C$. cf. brachyotis forest (Chiroptera: Pteropodidae) from Malaysia Using Multivariate Analysis. Zoological Studies, 51(2), 259-271.

Jayaraj, V. K., Nurul Farah Diyana, A.T., Noor Amirah, U., Noor Farahin, K.B., SitiKatijah, I. \& Siti Nor Azwa, Z. (2012b). Species diversity of small mammals at Gunung Stong State Park, Kelantan, Malaysia. Journal of Threatened Taxa, 4(6), 2617-2628.

Jayaraj, V. K., Daud, S. H. M., Azhar, M. I., Sah, S. A. M., Mokhtar, S. I. \& Abdullah, M. T. (2013). Diversity and conservation status of mammals in Wang Kelian State Park, Perlis, Malaysia. Check List, 9(6), 1439-1448.

Jayaraj, V. K., Khan, F. A. A., Azhar, I., Wee C. E., Ali, M. R. M., Ahmad, A., \& Yusoff, A. M. (2016). Diversity and conservation status of small mammals in Kelantan, Malaysia. Songklanakarin Journal of Science \& Technology, 38(2), 213-220.

Jenni, L. (1991). Microclimate of roost sites selected by wintering bramblings Fringilla montifringilla. Scandinavian Journal of Ornithology, 22(4), 327-334.

Kingston, T., Lim, B. L. \& Zubaid, A. (2006). Bats of Krau Wildlife Reserve. Selangor: Penerbit Universiti Kebangsaan Malaysia.

Kunz, T. H. \& Lumsden, L. F. (2003). Ecology of cavity and foliage roosting bats. In Bat
Ecology, (Ed.) Kunz, T. H. \& Fenton, M.

B. Chicago and London: University of Chicago Press, pp, 3-89.

Lim, B. L. (1970). Food habits and breeding cycle of the Malaysian fruit-eating bat, Cynopterus brachyotis. Journal of Mammalogy, 51(1), 174 - 177.

Lim, V. C., Ramli, R., Bhassu, S. \& Wilson, J. J. (2017). A checklist of the bats of Peninsular Malaysia and progress towards a DNA barcode reference library. PloS One, 12(7), e0179555.

Marimuthu, G., Rajan, K. E., Koilraj, A. J., Isaac, S.S. \& Balasingh, J. (1998). Observations on the foraging behaviour of a tent roosting megachiropteran, Cynopterus sphinx. Biotropica, 30, 321-324.

Mohd-Azlan, J., Neuchlos, J. \& Abdullah, M. T. (2005). Diversity of chiropterans in limestone forest area, Bau, Sarawak. Malaysian Applied Biology, 34(1), 59-64.

Mohd-Ridwan, A. R., Tahir, N. F. D.A., Mohamad Haikal, E., Csorba, G., Görföl, T., Khan, F. A. A. \& Mohd-Azlan, J. (2018). Bats assemblage and lunar phase effect on bat activity at mixed Dipterocarp Forest, Gunung Gading National Park, Sarawak, Borneo. Sains Malaysiana, 47(7), 13491357.

Morni, M. A., Khan, F. A. A., Rosli, Q. S., Dee, J. W., Tingga, R. C. T. \& Rahman, M. R. A. (2018). Bats roost site preferences in wind cave nature reserve, Bau, Sarawak. Malaysian Applied Biology, 47(1), 57-64.

Muhamad Aidil, Z., Candyrilla Vera, B. \& Abdullah, M.T. (2018). Fauna in Setiu Wetland forest. Kenyir Research Institute, Univerisiti Malaysia Terengganu.

Nicolai, V. (1986). The bark of trees: thermal properties, microclimate and fauna. Oecologia, 69(1), 148-160.

Pounsin, G., Nur Syahirah, W., Azuan, R., Muhamad Aidil, Z., Elizabeth, P., Nur Aida Md T. \& Abdullah, M.T. (2018). Diversity of bats in contrasting habitats of 
Hulu Terengganu Dipterocarp Forest and Setiu Wetland BRIS forest with a note on preliminary study of vertical stratification of vertical stratification of Pteropodid bats. Tropical Life Sciences Research, 29(1), 5169.

Rajasegaran, P., Shazali, N. \& Khan, F. A. A. (2018). Microclimate and physiological effects in the roosts of cave dwelling bats: Implications in roost selection and conservation in Sarawak, Malaysian Borneo. Zoological Science, 35(6), 521528.

Rovie-Ryan, J. J., Guan, A. K. H., Jayaraj, V. K., Esa, Y.B., Sallehin, A. A. \& Abdullah, M. T. (2008). Malaysian fruit bats phylogeny inferred using ribosomal RNA. Pertanika Journal of Tropical Agricultural Science, 31(1), 67-77.

Sedgeley, J. A. (2001). Quality of cavity microclimate as a factor influencing selection of maternity roosts by a treedwelling bat, Chalinolobus tuberculatus, in New Zealand. Journal of Applied Ecology, 38(2), 425-438.

Simmons, N. B. (2005). Order Chiroptera. In Mammal Species of the World: A Taxonomic and Geographic Reference, (Ed.) Wilson,

D.E. \& Reeder, D.M. Baltimore: Johns Hopkins University Press, pp, 312-529.

Storz, J. F. \& Kunz, T. H. (1999). Cynopterus sphinx. Mammalian Species, 613, 1-8. https://doi.org/10.2307/3504423.

Tamblyn, A., Turner, C. \& Raines, P. (2006). Malaysia Tropical Forest Conservation Project: A collaborative project between the Department of Wildlife and National Parks, Malaysia (PERHILITAN) and Coral Cay
Conservation. Report of the Setiu Wetlands Phase. Jaquelin Fisher Associates Ltd.

Tan, K. H., Zubaid, A. \& Kunz, T. H. (1997). Tent construction and social organization in Cynopterus brachyotis (Muller) (Chiroptera: Pteropodidae) in Peninsular Malaysia. Journal of Natural History, 31, 1605-1621.

Tan, K. H., Zubaid, A. \& Kunz, T. H. (1998). Food habits of Cynopterus brachyotis (Muller) (Chiroptera: Pteropodidae) in Peninsular Malaysia. Journal of Tropical Ecology, 14, 299-307.

Tingga, R. C. T., Khan, F. A. A., Ridwan, A. M., Senawi, J. \& Abdullah, M. T. (2012). Small mammals from Kuala Atok, Taman Negara Pahang, Malaysia. Sains Malaysiana, 41(6), 659-669.

Walsberg, G. E. (1985). Physiological consequences of microhabitat selection. In Habitat selection in birds, (Eds.) Cody, M. L. New York: Academic Press, pp, 389-413.

Welbergen, J. A., Klose, S. M., Markus, N. \& Eby, P. (2008). Climate change and the effects of temperature extremes on Australian flying-foxes. Proceedings of the Royal Society B, 275(1633), 419-425.

Wijayanti, F. (2011). Ekologi, Relung Pakan dan Strategi Adaptasi Kelelawar Penghuni Gua di Karst Gombong Kebumen Jawa Tengah. PHD Thesis. Agricultural University, Bogor.

Zahidin, M. A., Roslan, A., Marni, W., Kombi, M. \& Abdullah, M. T. (2016). Biodiversity assessment and updated checklist of faunal diversity in Bako National Park, Sarawak, Malaysia. Journal of Sustainability Science and Management, 11(1), 53-72. 